\title{
Retroviral Inhibition of cAMP-Dependent Protein Kinase Inhibits Myelination But Not Schwann Cell Mitosis Stimulated by Interaction with Neurons
}

\author{
Douglas G. Howe ${ }^{1}$ and Ken D. McCarthy ${ }^{1,2}$ \\ ${ }^{1}$ The Curriculum in Neurobiology and the 2Department of Pharmacology, The University of North Carolina, Chapel Hill, \\ North Carolina 27599
}

\begin{abstract}
Schwann cells are the myelinating glia of the peripheral nervous system. Neuron-Schwann cell contact profoundly affects several aspects of Schwann cell phenotype, including stimulation of mitosis and myelin formation. Many reports suggest that neuronal contact exerts this influence on Schwann cells by elevating Schwann cell cAMP and activating cAMP-dependent protein kinase $A(P K A)$. To elucidate the importance of Schwann cell PKA in neuronal stimulation of Schwann cell mitosis and myelination, the gene encoding the PKA inhibitory protein $\mathrm{RI} \alpha \mathrm{AB}$ or PKIEGFP was delivered to Schwann cells using retroviral vectors. PKA inhibitory retroviral vectors effectively blocked forskolin-stimulated Schwann cell mitosis and morphological change, demonstrating the ability of the vectors to inhibit PKA in infected Schwann cells. Treatment of dorsal root
\end{abstract}

Interaction between neurons and Schwann cells in the peripheral nervous system has many effects on Schwann cell phenotype, including elevation of Schwann cell mitotic rate (McCarthy and Partlow, 1976; Salzer and Bunge, 1980; Salzer et al., 1980) and expression of proteins and lipids critical for myelin formation (Politis et al., 1982; Sobue and Pleasure, 1984; Sobue et al., 1986; Shuman et al., 1988; Gupta et al., 1990, 1993; Mirsky et al., 1990; Morgan et al., 1991; Fernandez-Valle et al., 1993). Schwann cell division stimulated by neuron-Schwann cell interactions is critical during both normal development and regeneration after nerve damage (Bunge, 1994). The normal development of myelin by Schwann cells is essential to the proper function of the peripheral nervous system. Disruption of myelin formation results in significant peripheral neuropathies in humans, such as CharcotMarie-Tooth disease (Hayasaka et al., 1993; Kulkens et al., 1993; Oh et al., 1997; Marrosu et al., 1998). Hence, a detailed understanding of the molecular mechanisms responsible for neuronal modulation of Schwann cell phenotype is essential for elucidating the etiology of many peripheral neuropathies, as well as to facilitate regeneration after peripheral nerve damage. Despite its

Received Aug. 18, 1999; revised Feb. 22, 2000; accepted Feb. 22, 2000.

This work was supported by National Institute of Health Grants NS33938 and NS20212. We thank Dr. T. J. Murphy for providing PKIEGFP, Dr. Stanley McKnight for providing RI $\alpha \mathrm{AB}$, and Dr. Geoffrey Owens for providing the LiresNEO retroviral vector. In addition, we thank Dr. John Olsen and Dr. Geoffrey Owens for helpful discussion at the outset of this project. We also thank Debbie Clay for assistance with construction of LiresGFP.

Correspondence should be addressed to Dr. Ken D. McCarthy, Department of Pharmacology, CB\# 7365, The University of North Carolina at Chapel Hill, Chapel Hill, NC 27599. E-mail: kdmc@med.unc.edu.

Copyright (C) 2000 Society for Neuroscience $0270-6474 / 00 / 203513-09 \$ 15.00 / 0$ ganglia neuron-Schwann cell cocultures with $\mathrm{H}-89(10 \mu \mathrm{M})$ or KT5720 (1-10 $\mu \mathrm{M})$, chemical inhibitors selective for PKA, significantly inhibited neuronal stimulation of Schwann cell mitosis. In contrast, retrovirus-mediated inhibition of Schwann cell PKA had no effect on the ability of neurons to stimulate Schwann cell mitosis. However, markedly fewer myelin segments were formed by Schwann cells expressing PKA inhibitory proteins compared with controls. These results suggest that activation of Schwann cell PKA is required for myelin formation but not for Schwann cell mitosis stimulated by interaction with neurons.

Key words: PKA; PKI; RI $\alpha A B$; retrovirus; GFP; Schwann; neuron-glial interaction; myelin; mitosis critical nature, the molecular mechanisms mediating the neuronSchwann cell interaction are only beginning to be understood.

Mitosis and myelination are among several Schwann cell properties modulated in a similar manner by neuron-Schwann cell contact or treatment of cultured Schwann cells with cAMPelevating agents. These results suggest that neuronal contact may stimulate Schwann cell mitosis and myelin formation by elevating Schwann cell cAMP and activating the cAMP-dependent protein kinase A (PKA). However, Schwann cells must first be quiescent for cAMP elevation to promote the myelinating phenotype (Morgan et al., 1991). This observation suggests that, as Schwann cells differentiate into the myelinating lineage, their response to cAMP elevation may change from mitosis to induction of a myelin-related phenotype. Our studies were designed to test the hypothesis that Schwann cell PKA plays a critical role in the neuronal stimulation of Schwann cell mitosis and myelination.

To investigate the importance of Schwann cell PKA in neuronSchwann cell interactions, it is necessary to meet three basic criteria. First, PKA must be effectively inhibited. Second, inhibition must be specific for PKA. Third, the inhibition must be directed specifically to Schwann cells contacting neurons. In consideration of these criteria, we have used retroviral vectors to deliver genes encoding the PKA inhibitory proteins $\mathrm{RI} \alpha \mathrm{AB}$ or PKIEGFP specifically to Schwann cells in coculture with neurons from dorsal root ganglia (DRG). The dominant negative PKA regulatory subunit $\mathrm{RI} \alpha \mathrm{AB}$ has mutations in the two regulatory subunit cAMP binding sites. These mutations prevent cAMP binding to the regulatory subunit and consequently block release of the PKA catalytic subunit in response to elevation of cAMP concentration (McKnight et al., 1988; Corell et al., 1989; Woodford et al., 1989). PKIEGFP is the full-length rabbit skeletal 
muscle PKI $\alpha$ fused to the $\mathrm{N}$ terminus of the green fluorescent protein EGFP (Wang and Murphy, 1998). The ability of forskolin to stimulate mitosis and morphological changes in infected Schwann cells was examined to confirm inhibition of PKA. The role of Schwann cell PKA in neuronal stimulation of Schwann cell mitosis and myelination was then examined. Our results suggest an important role for Schwann cell PKA in myelination but not in neuronal stimulation of Schwann cell mitosis.

\section{MATERIALS AND METHODS}

Dorsal root ganglia explant cultures. Culture surfaces were pretreated for 60 min with a 1:25 dilution of Matrigel (Collaborative Research, Bedford, MA) in Basal Medium Eagles (BME), rinsed once, and treated for $30 \mathrm{~min}$ with $10 \mu \mathrm{g} / \mathrm{ml}$ poly-D-lysine. Spinal cords were dissected from embryonic day 15-18 rat pups and placed into HBSS with $1.26 \mathrm{~mm}$ calcium chloride, $810 \mu \mathrm{M}$ magnesium sulfate, $10 \mathrm{mM}$ HEPES, $5 \%$ fetal calf serum (FCS), $50 \mathrm{U} / \mathrm{ml}$ penicillin, and $50 \mu \mathrm{g} / \mathrm{ml}$ streptomycin on ice. Spinal cords were then moved to a second dish containing the same medium in which the DRG were removed with fine forceps. DRG were transferred to a third dish containing the same medium before plating in BME supplemented with the following: $5 \mu \mathrm{g} / \mathrm{L}$ human recombinant insulin, $5 \mu \mathrm{g} / \mathrm{L}$ human transferrin, and $5 \mathrm{ng} / \mathrm{L}$ selenous acid (ITS) (Collaborative Research), 0.2\% BSA, $10 \mathrm{~mm} \mathrm{HEPES,} 100 \mathrm{ng} / \mathrm{ml} 2.5 \mathrm{~S}$ NGF (Collaborative Research) and 1\% FCS (BME-ITS-BHN 1\% FCS). Schwann cells derived from these DRG explants have been denoted $\mathrm{SC}_{\mathrm{DRG}}$. Myelinating DRG cultures were established by plating three ganglia per well in a triangular arrangement in 12 well plates. Cultures were maintained in a $37^{\circ} \mathrm{C}$ incubator with $93 \%$ air and $7 \% \mathrm{CO}_{2}$. Myelin formation was initiated 7-10 d after infection by changing to myelinating medium consisting of DMEM-high glucose $(\mathrm{H})$ containing $5.0 \mathrm{gm} / \mathrm{L}$ D-glucose, $2 \mathrm{~mm}$ glutamine, $100 \mathrm{ng} / \mathrm{ml} \mathrm{2.5S} \mathrm{NGF,} 15 \%$ heat-inactivated FCS, and $50 \mu \mathrm{g} / \mathrm{ml}$ ascorbic acid (MM+).

Sciatic nerve Schwann cell cultures. Sciatic nerves were removed from newborn Sprague Dawley rat pups and placed into DMEM-H with 10 mM HEPES (HE) on ice until dissections were complete. The nerves were treated for $20 \mathrm{~min}$ in a gently shaking water bath at $37^{\circ} \mathrm{C}$ in $\mathrm{HE}$ with $0.03 \%$ collagenase (Serva Feinbiochemica, Heidelberg, Germany). The medium was then replaced with the same solution supplemented with $0.25 \%$ trypsin and returned to the shaking water bath for $20 \mathrm{~min}$. The medium was replaced twice with $2.0 \mathrm{ml}$ of DMEM-H 10\% FCS, and the nerves were triturated using a fire-polished glass pipette. The suspension was plated at a density of two nerves per $9.6 \mathrm{~cm}^{2}$ plate and maintained in a $37^{\circ} \mathrm{C}$ incubator with $95 \%$ air and $5 \% \quad \mathrm{CO}_{2}$. The following day, the medium was supplemented to contain $10 \mu \mathrm{M}$ cytosine $\beta$-D-arabinofuranoside (AraC) to kill dividing fibroblasts. After $72 \mathrm{hr}$, this medium was replaced with fresh medium lacking AraC.

Retroviral vectors. The retroviral vector LiresGFP was derived from the vector LiresNEO+env (a gift from Dr. Geoff Owens, University of Colorado Health Sciences Center, Denver, CO). LiresNEO+env was cut with BstXI and ClaI to remove the neo coding region and the NcoI site at 2229. An adapter was ligated in its place adding a Not I site to create the plasmid N-Lires-2. The hGFP(S65T) coding region, obtained as a NotI fragment from pTRBS-UF2 (Zolotukhin et al., 1996), was ligated into NotI digested N-Lires-2 to produce LiresGFP.

To create the PKA inhibitory retroviral vector RI $\alpha$ ABiresGFP, the dominant negative regulatory subunit $\mathrm{RI} \alpha \mathrm{AB}$ was generated by PCR using plaque-forming units polymerase (Stratagene, La Jolla, CA) and MTREV $_{\mathrm{AB}}$ (a gift from Dr. Stanley McKnight, University of Washington, Seattle, WA) as a template. The primers BamRI $\alpha 5^{\prime}$ (5'-ATA GGA TCC ACC TGA GAA CCA TGG CGT CTG-3') and RI $\alpha 3^{\prime}$ (5'-ATA GGA TCC TCA GAC GGA CAG GGA C-3') overlapped the translation initiation codon and the stop codon at the $5^{\prime}$ and $3^{\prime}$ ends, respectively, and added Bam HI restriction sites flanking the PCR product. The PCR product was ligated into the Bam HI site of LiresNEO+env to produce RI $\alpha$ ABiresNEO. LiresGFP and RI $\alpha$ ABiresNEO were cut with XbaI releasing the iresGFP and iresNEO fragments, respectively. The iresGFP fragment was then ligated into the $X b a$ I digested RI $\alpha$ ABiresNEO in place of the analogous iresNEO fragment to produce RI $\alpha$ ABiresGFP.

PKIEGFP and EGFP coding sequences were derived from pTJM2PKIEGFP (Wang and Murphy, 1998). PKIEGFP is a fusion gene consisting of the full-length rabbit skeletal muscle PKI $\alpha$ fused to the $5^{\prime}$ end of the green fluorescent protein EGFP. pTJM2PKIEGFP was modified by the addition of an adapter $5^{\prime}$ of the PKIEGFP coding region between the HinDIII and SacI sites. The adapter, composed of oligonucleotide DH8-67-3 (5'-CAG ATC TTC AAG TTA ACC TGC GGA TCC A-3') and oligonucleotide DH8-67-4 (5'-AGC TTG GAT CCG CAG GTT AAC TTG AAG ATC TGA GCT-3'), added 5'-BglII-HpaIBamHI-3' restriction sites $5^{\prime}$ of the PKIEGFP coding sequence. A second adapter composed of oligonucleotides DH8-67-1 (5'-CTA GGT AGA TCT TGC-3') and DH8-67-2 (5'-GGC CGC AAG ATC TAC-3') was inserted between the $X b a \mathrm{I}$ and Not I sites $3^{\prime}$ of the PKIEGFP coding region, adding a $B g l \mathrm{II}$ restriction site and producing the plasmid pTJM2PKIEGFP2. The PKIEGFP coding region was then released by digestion with $B g l \mathrm{II}$ and ligated into the Bam HI site of LiresNEO to produce PKIEGFPIN. EGFPIN was constructed from PKIEGFPIN by digestion with Bam $\mathrm{HI}$ to release only the PKI coding sequence. The vector was then religated to produce the control plasmid EGFPIN.

Virus production. GP + E86 cells (Dr. J. Olsen, University of North Carolina at Chapel Hill, Chapel Hill, NC) $\left(0.5-1.0 \times 10^{6}\right)$ were plated in $28.3 \mathrm{~cm}^{2}$ dishes in DMEM-H $10 \% \mathrm{FCS}$ and maintained in a $37^{\circ} \mathrm{C}$ incubator with $95 \%$ air and $5 \% \mathrm{CO}_{2}$. The day after plating, the cells were transfected with $20 \mu \mathrm{g}$ of plasmid DNA by the calcium phosphate precipitation method. For LiresGFP and RI $\alpha$ ABiresGFP, which lack an antibiotic selectable marker, cotransfection was performed using a total of $20 \mu \mathrm{g}$ of DNA with the viral plasmid and PCDNA3.1 in a 10:1 molar ratio, respectively. After a $24 \mathrm{hr}$ incubation of the cells with the DNA precipitate, the medium was replaced. Selection in G418 (400 $\mu \mathrm{g} / \mathrm{ml}$ active) was begun on the second day after transfection. Confluent 176.6 $\mathrm{cm}^{2}$ plates of packaging cells were maintained in $12 \mathrm{ml}$ of medium with $10 \mathrm{~mm} n$-butyric acid for $3 \mathrm{~d}$, during which time the virus was harvested and the medium replaced every $24 \mathrm{hr}$. The harvested medium containing retroviral vectors was filtered through a $0.45 \mu \mathrm{m}$ syringe filter before infections.

Infection protocols. On the third day in culture, DRG explants in 12 well plates were exposed to $1.5-1.75 \mathrm{ml}$ of packaging cell conditioned medium with $8 \mu \mathrm{g} / \mathrm{ml}$ polybrene for $2 \mathrm{hr}$ at $37^{\circ} \mathrm{C}$ in a $5 \% \mathrm{CO}_{2}$ and $95 \%$ air incubator. Cultures were rinsed twice with $\mathrm{BME}$ and returned to BME-ITS-BHN with $1 \%$ FCS. This procedure was repeated on the fourth and fifth days in culture.

Sciatic nerve Schwann cells were cultured overnight in DMEM-H 10\% FCS with $2 \mu \mathrm{M}$ forskolin and $40 \mu \mathrm{g} / \mathrm{ml}$ bovine pituitary extract (BPE). Cells cultured in $28.3 \mathrm{~cm}^{2}$ dishes were exposed to $4-5 \mathrm{ml}$ of packaging cell conditioned medium plus $8 \mu \mathrm{g} / \mathrm{ml}$ polybrene for $2 \mathrm{hr}$ in a $37^{\circ} \mathrm{C}$ incubator with $5 \% \mathrm{CO}_{2}$ and $95 \%$ air. Cultures were then rinsed twice in DMEM-H and returned to DMEM-H $10 \%$ FCS with forskolin and BPE. This procedure was repeated on 3 consecutive days. After the third infection, cultures were maintained in DMEM-H 10\% FCS. Where appropriate, the cells were selected in DMEM-H 10\% FCS with 500 $\mu \mathrm{g} / \mathrm{ml} \mathrm{G} 418$.

5-Bromo-2'-deoxyuridine immunocytochemistry. DRG explant cultures were treated with $50 \mu \mathrm{M} 5$-bromo-2'-deoxyuridine (BrdU) for $24 \mathrm{hr}$ in defined medium (BME-ITS-BHN). Cultures were rinsed once in PBS and fixed for $10 \mathrm{~min}$ at $4^{\circ} \mathrm{C}$ with $4 \%$ paraformaldehyde in $\mathrm{PBS}, \mathrm{pH} 7.3$. Subsequently, cultures were rinsed once in PBS and treated at room temperature for 10 min with $100 \%$ methanol, 20 min with $2 \mathrm{~N} \mathrm{HCl}$, and three times for $3 \mathrm{~min}$ each with $0.1 \mathrm{M}$ sodium borate buffer, $\mathrm{pH}$ 8.5. After rinsing twice for 5 min each in PBS with $0.5 \%$ BSA and $10 \mathrm{~mm}$ HEPES, pH 7.4 (PBS-H-BSA), the primary antibodies [rabbit anti-rGFP IgG, 1:100 (Clontech, Cambridge, UK) and mouse anti-BrdU IgG, 1:50 (Boehringer Mannheim, Indianapolis, IN)] were applied in PBS-H-BSA for $30 \mathrm{~min}$ at $25^{\circ} \mathrm{C}$. It was necessary to immunostain for GFP because the BrdU staining protocol destroyed the GFP chromophore. After three washes of 5 min each in PBS-H-BSA with $10 \%$ normal goat serum, secondary antibodies [FITC-conjugated goat anti-rabbit IgG, 1:400 (Cappel, West Chester, PA) and rhodamine conjugated goat anti-mouse $\operatorname{IgG}, 1: 100$ (Cappel)] were applied in the same solution for $30 \mathrm{~min}$. Cultures were rinsed three times for $5 \mathrm{~min}$, once with PBS, and mounted in PBS/glycerol (50:50).

Sudan black staining. DRG explants were grown in $\mathrm{MM}+$ for $10 \mathrm{~d}$ to promote myelin formation. After fixation for $10 \mathrm{~min}$ at room temperature with $4 \%$ paraformaldehyde in $\mathrm{PBS}, \mathrm{pH} 7.4$, cultures were osmicated with $0.1 \% \mathrm{OsO}_{4}$ in $\mathrm{PBS}, \mathrm{pH} 7.4$, for $1 \mathrm{hr}$ and dehydrated in a graded series of ethanol $(25,50$, and $70 \% ; 5$ min each). Cultures were then stained with a solution of $0.5 \%$ Sudan black in $70 \%$ ethanol for $1 \mathrm{hr}$ at room temperature, rinsed for $<30 \mathrm{sec}$ in $70 \%$ ethanol, rehydrated with PBS, $\mathrm{pH} 7.4$, and mounted in PBS/glycerol (50:50).

Forskolin stimulation of mitosis. Sciatic nerve Schwann cells infected with EGFPIN or PKIEGFPIN and selected in G418 were harvested with 
$0.2 \%$ trypsin and resuspended in DMEM-H $10 \%$ FCS. The cells were plated at low density ( $\sim 1200$ cells per well) into poly-D-lysine-coated 12 well plates. After $24 \mathrm{hr}$, the medium was changed to DMEM-H $2 \%$ FCS supplemented with the following: (1) nothing; (2) $2 \mu \mathrm{M}$ forskolin; (3) 40 $\mu \mathrm{g} / \mathrm{ml} \mathrm{BPE}$; or (4) $2 \mu \mathrm{M}$ forskolin and $40 \mu \mathrm{g} / \mathrm{ml} \mathrm{BPE}$. The media were replaced daily for 5-6 d. The number of Schwann cells in each of $\sim 100$ GFP-positive $\left(\mathrm{GFP}^{+}\right)$clones per well was then determined.

For analysis of forskolin-stimulated mitosis using infected $\mathrm{SC}_{\mathrm{DRG}}$, a single DRG was cultured in each well of a 12 well plate and infected as described above. After infection, cultures were maintained in BME-ITSBHN for 2-4 d. Neuronal cell bodies were then removed by aspiration with a $200 \mu$ l pipette tip connected to a vacuum system, and the Schwann cells were harvested with $0.25 \%$ trypsin and a cell scraper. Cells harvested from three ganglia were pooled, an equal volume of DMEM-H $10 \%$ FCS was added, and cells were aspirated gently with a fire-polished glass pipette. The suspension was pelleted and resuspended in $100 \mu \mathrm{l}$ of the same medium for counting with a hemacytometer. Cells were then diluted to $\sim 1000$ cells $/ \mathrm{ml}$ in the same medium and plated into six wells of a glass-bottom poly-D-lysine-coated 12 well plate $(1 \mathrm{ml} /$ well). After $48 \mathrm{hr}$, the serum was reduced to $2 \%$, and the cells were cultured in the presence and absence of $2.0 \mu \mathrm{M}$ forskolin. Media were changed every $2 \mathrm{~d}$ for $10 \mathrm{~d}$. The average number of EGFP ${ }^{+}$(PKIEGFPIN and EGFPIN) or total (LiresGFP or RI $\alpha$ ABiresGFP) Schwann cells per field was determined by counting Schwann cells in 10 random fields $\left(0.29 \mathrm{~cm}^{2}\right.$ each) per coverslip.

Forskolin effects on morphology. DRG explants were cultured and infected as described for forskolin stimulation of $\mathrm{SC}_{\mathrm{DRG}}$ mitosis. For each virus, the Schwann cells harvested from three wells were pooled, pelleted, resuspended in $6 \mathrm{ml}$ of DMEM-H $10 \% \mathrm{FCS}$, and plated into six wells of a glass-bottom 12 well plate $(1 \mathrm{ml} /$ well $)$. After $48 \mathrm{hr}$, the medium was changed to DMEM-H 10\% FCS with or without $2.0 \mu \mathrm{M}$ forskolin. Media were replaced every $2 \mathrm{~d}$ for $4-6 \mathrm{~d}$ to promote morphological change.

Sciatic nerve Schwann cells were infected on 3 consecutive days with the retroviral vector EGFPIN or PKIEGFPIN and selected in G418. Infected cells were harvested with trypsin and replated into 12 well plates in DMEM-H $10 \%$ FCS $\left(\sim 10^{4}\right.$ cells per well). After $24 \mathrm{hr}$ the medium was replaced with DMEM-H 10\% FCS with or without $2 \mu \mathrm{M}$ forskolin. Cultures were maintained in these media for 4-6 d, with media changed every other day.

Neuronal stimulation of mitosis. DRG explants were maintained and $\mathrm{SC}_{\mathrm{DRG}}$-infected as described above. On the seventh day in culture $(2 \mathrm{~d}$ after infection), the culture medium was supplemented with $\mathrm{BrdU}$ (50 $\mu \mathrm{M})$. After a $24 \mathrm{hr}$ pulse with BrdU, cultures were processed for GFP and BrdU immunocytochemistry as described above. For EGFPIN- and PKIEGFPIN-infected cells, the percentage of $\mathrm{BrdU}^{+}$cells of 100-200 $\mathrm{GFP}^{+}$cells was determined for each coverslip. For LiresGFP- and $\mathrm{RI} \alpha \mathrm{ABiresGFP}-$ infected cells, the percentage of $\mathrm{BrdU}^{+}$cells in a random population of 100-200 cells per coverslip was determined. This was necessary because the signal after immunocytochemical detection of GFP in cells infected with LiresGFP or RI $\alpha$ ABiresGFP was often too low to permit confident distinction between cells that were and cells that were not expressing GFP.

The effects of chemical inhibitors of PKA on neuronal stimulation of mitosis were also examined. Noninfected DRG explant cultures were exposed to H-89 $(10 \mu \mathrm{M})$ or KT5720 $(1-10 \mu \mathrm{M})$ for $48 \mathrm{hr}$ on the sixth and seventh days in culture. The media were replaced with fresh PKA inhibitors and $50 \mu \mathrm{M}$ BrdU for the final $24 \mathrm{hr}$. Cultures were then fixed and immunostained for BrdU as described above. In all cases, analysis was limited to the periphery of the cultures in which Schwann cell density was lowest to avoid contact inhibition of Schwann cell mitosis.

\section{RESULTS}

\section{Infection with PKA inhibitory retroviral vectors blocks forskolin-stimulated Schwann cell mitosis and morphological change}

We have created two control (EGFPIN and LiresGFP) and two PKA inhibitory (RI $\alpha$ ABiresGFP and PKIEGFPIN) retroviral vectors (Fig. 1). The small amount of Schwann cell protein $(<20$ $\mu \mathrm{g}$ ) obtained from infected preparations prevented the use of traditional in vitro biochemical assays to directly evaluate the inhibition of PKA in infected Schwann cells. However, elevation of cAMP in Schwann cells has been shown previously to syner-

\section{LiresGFP}

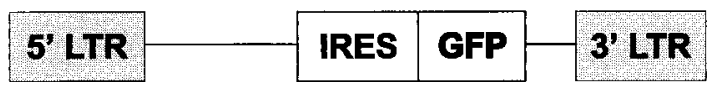

\section{RlaABiresGFP}

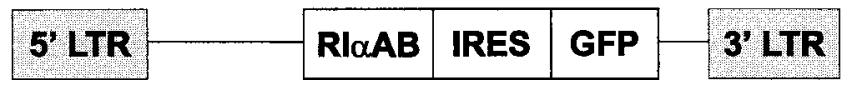

\section{EGFPIN}

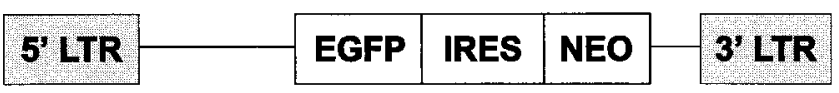

PKIEGFPIN

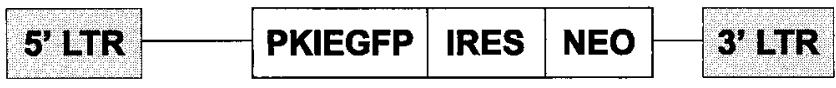

Figure 1. Structure of recombinant retroviruses for inhibition of PKA. The retroviral $5^{\prime}$ long-terminal repeat $(L T R)$ drives expression of the encoded genes in infected cells. Control vectors have nothing (LiresGFP) or EGFP (EGFPIN) cloned $5^{\prime}$ of the encephalomyocarditis virus ires. PKA inhibitory vectors have either the dominant negative PKA regulatory subunit $\mathrm{RI} \alpha \mathrm{AB}$ (RI $\alpha \mathrm{ABiresNeo)}$ or PKIEGFP (PKIEGFPIN) cloned $5^{\prime}$ of the ires. $3^{\prime}$ of the IRES is either GFP(S65T) $(G F P)$ or the neomycin resistance gene (NEO).

gistically stimulate mitosis in the presence of growth factors and to cause a dramatic morphological change in Schwann cells. We used the adenylyl cyclase activator forskolin to stimulate mitosis and morphological changes in infected Schwann cells as indirect bioassays to test the ability of the retroviral vectors RI $\alpha$ ABiresGFP and PKIEGFPIN to inhibit PKA.

Sciatic nerve Schwann cells were infected with the control vector EGFPIN or the PKA inhibitory vector PKIEGFPIN, resulting in striking GFP expression in $\sim 70 \%$ of the Schwann cells. Low-density cultures of infected Schwann cells were grown for $4 \mathrm{~d}$ in $2 \%$ FCS medium, or $2 \%$ FCS medium with $2 \mu \mathrm{M}$ forskolin, $40 \mathrm{ng} / \mathrm{ml}$ bovine pituitary extract, or both. The number of Schwann cells in $\mathrm{GFP}^{+}$clones was then determined. Infection with PKIEGFPIN completely blocked Schwann cell mitosis stimulated by forskolin but had no effect on mitosis stimulated by bovine pituitary extract (Fig. 2).

The majority of our studies use the DRG explant system to isolate Schwann cells and examine neuron-Schwann cell interactions. The protocol used to infect $\mathrm{SC}_{\mathrm{DRG}}$ differed significantly from that used to infect sciatic nerve Schwann cells. Therefore, the retroviral vectors LiresGFP, RI $\alpha$ ABiresGFP, EGFPIN, and PKIEGFPIN were also examined for their ability to block forskolin-stimulated mitosis and morphological changes in $\mathrm{SC}_{\text {DRG}} . \mathrm{SC}_{\text {DRG }}$ were infected with a control vector (LiresGFP or EGFPIN) or a PKA inhibitory vector (RI $\alpha$ ABiresGFP or PKIEGFPIN), resulting in visible GFP expression by $>90 \%$ of the $\mathrm{SC}_{\mathrm{DRG}}$ (Howe and McCarthy, 1998). After infection and 3-5 $\mathrm{d}$ of expansion on the bed of DRG neurites, the Schwann cells were replated at low density and grown for $10 \mathrm{~d}$ in medium with 


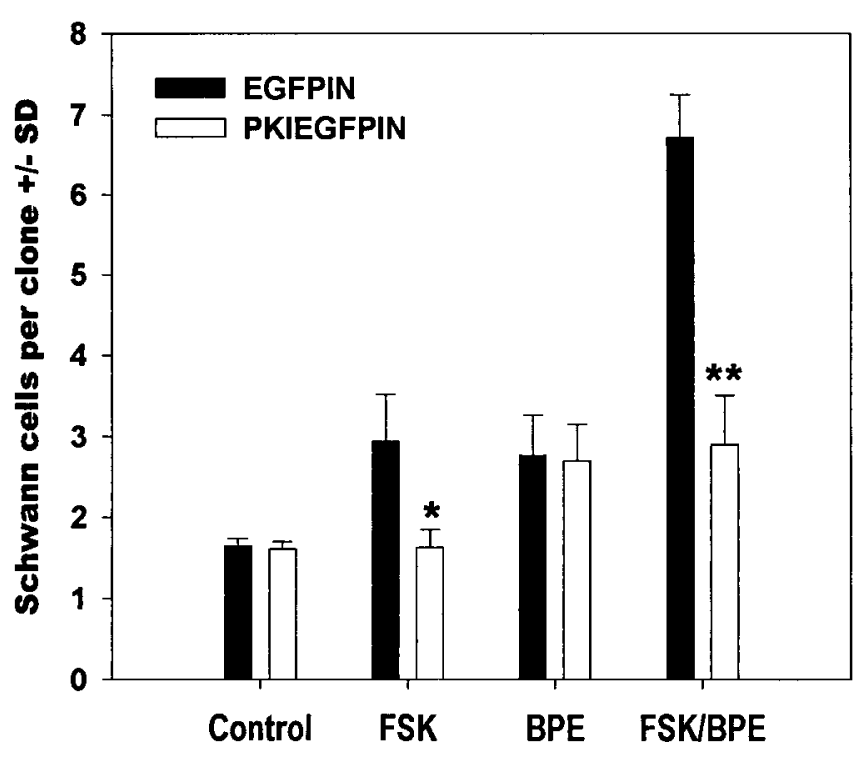

Figure 2. Infection of sciatic nerve Schwann cells with PKIEGFPIN blocks forskolin-stimulated but not BPE-stimulated Schwann cell mitosis. Sciatic nerve Schwann cells were infected with the retroviral vectors EGFPIN or PKIEGFPIN and selected in G418. The infected population was then plated at low density in a 12 well plate in medium with $10 \%$ FCS. After $24 \mathrm{hr}$, the medium was changed to $2 \% \mathrm{FCS}$ (Control) in the presence of $2 \mu \mathrm{M}$ forskolin $(F S K), 40 \mu \mathrm{g}$ of BPE, or both $(F S K / B P E)$. Cultures were maintained for $4 \mathrm{~d}$ in each condition. The number of cells in each of $\sim 100 \mathrm{GFP}^{+}$clones per well was then determined. Significance of differences from three independent experiments was determined by a $t$ test $\left(n=3 ;{ }^{*} p<0.02 ;{ }^{*} p<0.002\right)$.

$2 \% \mathrm{FCS}$ in the presence or absence of $2 \mu \mathrm{M}$ forskolin. The number of $\mathrm{EGFP}^{+}$(EGFPIN and PKIEGPIN) or total (LiresGFP and RI $\alpha$ ABiresGFP) $\mathrm{SC}_{\text {DRG }}$ in 10 random fields $\left(0.29 \mathrm{~cm}^{2}\right.$ each) per culture was determined. The high percentage of cells that were infected by LiresGFP and RI $\alpha$ ABiresGFP permitted analysis of the total population as opposed to focusing only on the $\mathrm{GFP}^{+}$cells. Stimulation with forskolin $(2.0 \mu \mathrm{M})$ increased the average number of EGFPIN- or LiresGFP-infected $\mathrm{SC}_{\text {DRG }}$ from $2-3$ to $40-60$ cells per field. In contrast, only $2-5$ cells per field were observed in PKIEGFPIN- or RI $\alpha$ ABiresGFP-infected cells, even when stimulated with forskolin (Fig. 3). These findings demonstrate that retroviral delivery of either the PKA dominant negative regulatory subunit $\mathrm{RI} \alpha \mathrm{AB}$ or the PKA inhibitor PKIEGFP effectively blocks forskolin-stimulated Schwann cell mitosis and strongly suggest that PKA is functionally inhibited in Schwann cells infected with PKA inhibitory retroviral vectors.

Elevation of cAMP causes Schwann cells to change from a spindle-shaped to a flattened morphology with fenestrated cytoplasmic expansions (Sobue et al., 1986; Morgan et al., 1991). The ability of forskolin to cause this morphological change in infected $\mathrm{SC}_{\mathrm{DRG}}$ was examined as a second indirect evaluation of PKA activity in infected Schwann cells. Infected $\mathrm{SC}_{\mathrm{DRG}}$ were harvested, replated at low density, and exposed to $2 \mu \mathrm{M}$ forskolin for $4 \mathrm{~d}$ in $10 \%$ FCS. SC $_{\text {DRG }}$ infected with EGFPIN exhibited a spindle-shaped morphology in the absence of forskolin and a flattened morphology in the presence of forskolin (Fig. 4A, $B$, respectively). $\mathrm{SC}_{\text {DRG }}$ infected with PKIEGFPIN also exhibited a spindle-shaped morphology in the absence of forskolin but did not demonstrate any morphological change in response to treatment with forskolin (Fig. $4 C, D$, respectively). Similar results were obtained with $\mathrm{SC}_{\mathrm{DRG}}$ infected with LiresGFP or RI $\alpha$ ABiresGFP,

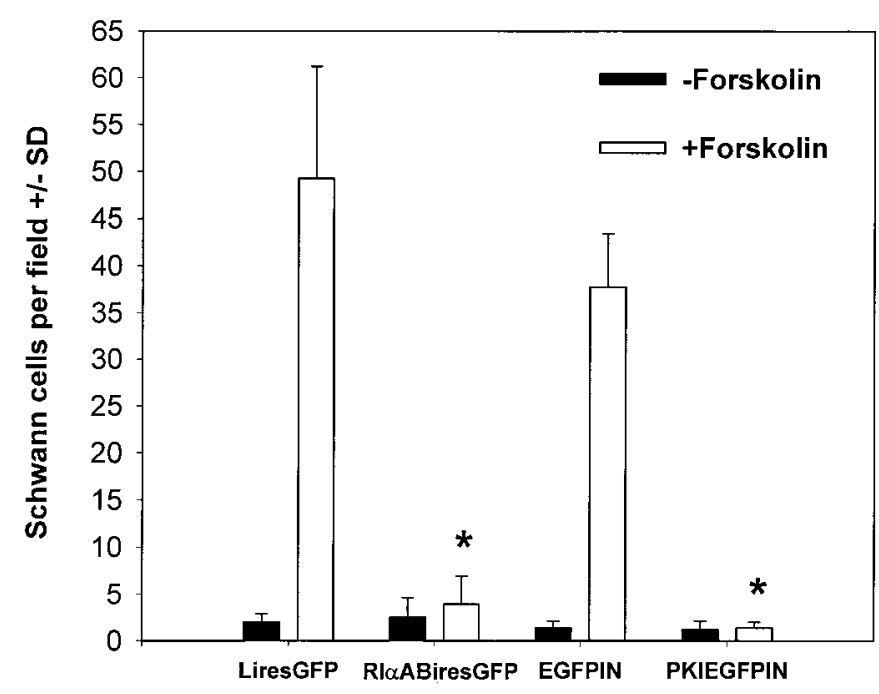

Figure 3. Infection of Schwann cells expanding from DRG explants with PKIEGFPIN or RI $\alpha$ ABiresGFP blocks forskolin-stimulated Schwann cell mitosis. Schwann cells expanding from DRG explants were infected on 3 consecutive days with the retroviral vector LiresGFP, EGFPIN, RI $\alpha$ ABiresGFP, or PKIEGFPIN. After a brief period of expansion on neurites, the Schwann cells were replated at low density and maintained for $8 \mathrm{~d}$ in medium with $2 \%$ FCS in the presence or absence of $2 \mu \mathrm{M}$ forskolin. The number of $\mathrm{GFP}^{+}$(EGFPIN and PKIEGFPIN) or total (LiresGFP and RI $\alpha$ ABiresGFP) Schwann cells per $0.29 \mathrm{~cm}^{2}$ field was determined in 10 random fields per coverslip. Forskolin stimulation caused an extensive mitotic response in Schwann cells infected with the control vectors LiresGFP and EGFPIN. In contrast, forskolin-stimulated mitosis was completely inhibited in Schwann cells infected with the PKA inhibitory retroviral vectors RI $\alpha$ ABiresGFP and PKIEGFPIN. Data are the mean \pm SD from three independent experiments. Significance of differences was determined with a $t$ test $\left(n=3 ;{ }^{*} p<0.005\right)$.

as well as sciatic nerve Schwann cells infected with EGFPIN and PKIEGFPIN (data not shown). Overall, these results strongly suggest that infection of sciatic nerve Schwann cells or $\mathrm{SC}_{\mathrm{DRG}}$ with PKIEGFP or RI $\alpha$ ABiresGFP functionally blocked PKAdependent signaling.

\section{Inhibition of Schwann cell PKA does not inhibit neuronal stimulation of Schwann cell mitosis}

To test the role of Schwann cell PKA in the neuronal stimulation of Schwann cell mitosis, DRG explants were exposed to chemical inhibitors of PKA, as well as PKA inhibitory retroviral vectors. H-89 $(10 \mu \mathrm{M})$ or KT5720 $(1-10 \mu \mathrm{M})$, chemical inhibitors selective for PKA (Kase et al., 1987; Chijiwa et al., 1990), were applied to noninfected DRG explants for $48 \mathrm{hr}$ starting on the sixth day in culture. Fresh medium and inhibitor with $\operatorname{BrdU}(50 \mu \mathrm{M})$ were added for the last $24 \mathrm{hr}$. Incorporated BrdU was detected by immunocytochemistry. Approximately $70 \%$ of the control $\mathrm{SC}_{\mathrm{DRG}}$ were $\mathrm{BrdU}^{+}$(Fig. 5). H-89 $(10 \mu \mathrm{M})$ reduced the percentage of $\mathrm{BrdU}^{+}$Schwann cells to $30 \%$ (Fig. 5), a result in agreement with that of Kim et al. (1997). KT5720 (10 $\mu \mathrm{M})$ had a similar effect, reducing the percentage of $\mathrm{BrdU}^{+} \mathrm{SC}_{\mathrm{DRG}}$ to $<10 \%$ (Fig. 5). In marked contrast to the results obtained with $\mathrm{H}-89$ and KT5720, inhibition of PKA in $\mathrm{SC}_{\mathrm{DRG}}$ by infection with PKIEGFPIN or $\mathrm{RI} \alpha \mathrm{ABiresGFP}$ had no effect on the neuronal stimulation of Schwann cell mitosis (Fig. 5).

\section{Inhibition of Schwann cell PKA inhibits myelin formation}

Elevation of cAMP promotes expression of a myelin-related phenotype in Schwann cells (Morgan et al., 1991). In addition, 


\section{-Forskolin}
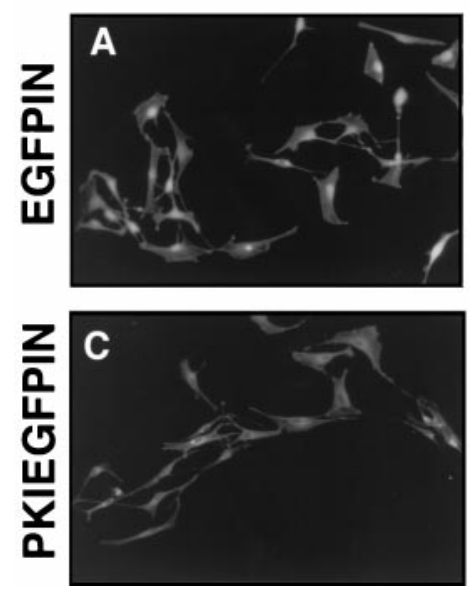

+Forskolin
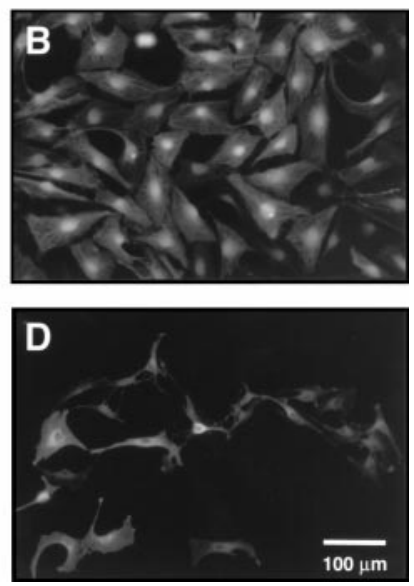

Figure 4. Infection of Schwann cells expanding from DRG explants with PKIEGFPIN blocks forskolin-stimulated Schwann cell morphological changes. Schwann cells expanding from DRG explant cultures were infected on 3 consecutive days with the retroviral vectors EGFPIN or PKIEGFPIN. Infected Schwann cells were replated and grown in $10 \%$ FCS in the absence $(A, C)$ or presence $(B, D)$ of $2 \mu \mathrm{M}$ forskolin for $4 \mathrm{~d}$. Infection of Schwann cells with PKIEGFPIN completely blocked the ability of forskolin to stimulate a morphological change. Similar observations were made with $\mathrm{SC}_{\mathrm{DRG}}$ infected with LiresGFP or RI $\alpha$ ABiresGFP. Scale bar, $100 \mu \mathrm{m}$.

neuronal contact and myelination are correlated with the elevation of cAMP levels in myelinating nerves by regulation of Schwann cell adenylyl cyclase and phosphodiesterase activities (Poduslo et al., 1995; Walikonis and Poduslo, 1998). These reports suggest that elevation of Schwann cell cAMP and activation of PKA may be an important signal in the initiation or maintenance of myelination by Schwann cells. The involvement of Schwann cell PKA in myelination was examined using $\mathrm{SC}_{\mathrm{DRG}}$ infected with PKA inhibitory retroviral vectors. Infected $\mathrm{SC}_{\mathrm{DRG}}$ were maintained in $\mathrm{MM}+$ for $10 \mathrm{~d}$ to promote myelin formation. After 4-5 d in $\mathrm{MM}+$, structures resembling the initial stages of myelination were clearly visible in the EGFP-expressing cultures, whereas such structures were virtually absent from PKIEGFPexpressing cultures. Myelin appeared as long stretches of parallel $\mathrm{EGFP}^{+}$Schwann cell profiles. By $7 \mathrm{~d}$ in $\mathrm{MM}+$, myelin segments were clearly visible on examination of EGFPIN-infected cultures under phase optics. Frequently, these myelin segments were $\mathrm{EGFP}^{+}$on examination under epifluorescence (Fig. 6A,B). In contrast, little myelin formation was observed in PKIEGFPINinfected cultures on examination with phase-contrast microscopy, and PKIEGFP ${ }^{+}$myelin segments were virtually absent on examination with epifluorescence microscopy (Fig. 6C,D). In LiresGFP- and RI $\alpha$ ABiresGFP-infected cultures, many Schwann cells were clearly expressing GFP. However, low ires-mediated GFP expression and high cell density precluded accurate determination of whether the myelin was elaborated by infected $\mathrm{SC}_{\text {DRG }}$. To quantify the myelin segments produced by infected Schwann cells, cultures were stained with Sudan black after $10 \mathrm{~d}$ in $\mathrm{MM}+$. On examination with phase-contrast microscopy, a marked overall decrease in the density of myelin segments was observed in cultures infected with PKIEGFPIN or RI $\alpha$ ABiresGFP compared with EGFPIN or LiresGFP (Fig. 7A). Schwann cell bodies associated with Sudan black-stained myelin segments were counted over the entire area of cultures. Infection

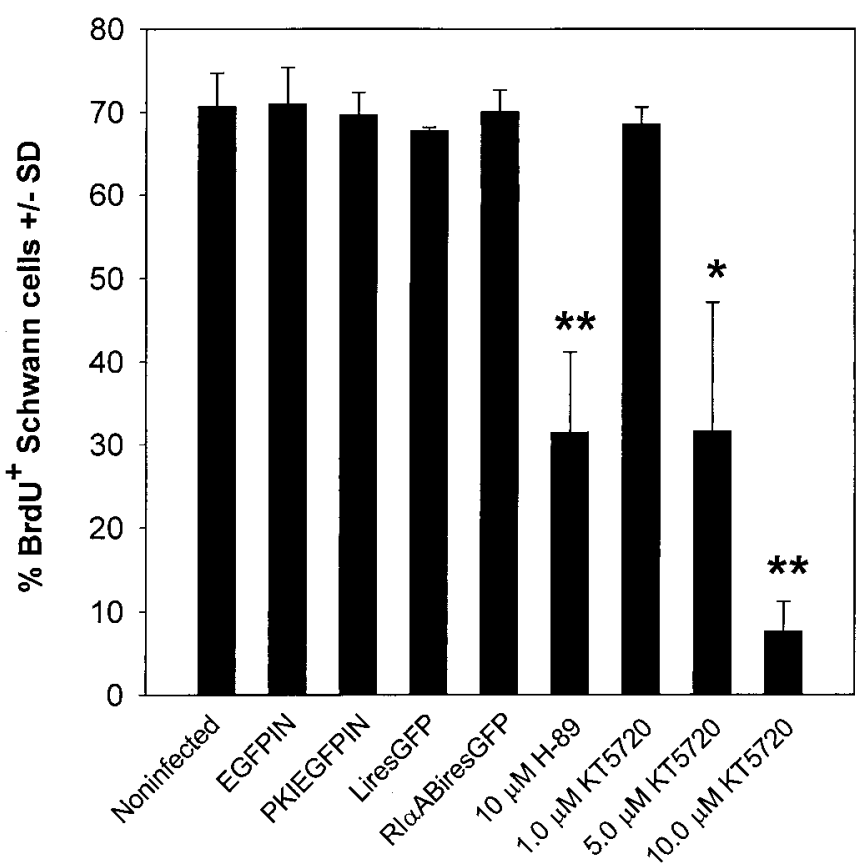

Figure 5. Inhibition of PKA selectively in Schwann cells does not inhibit neuronal stimulation of Schwann cell mitosis. $\mathrm{SC}_{\mathrm{DRG}}$ were left uninfected or infected with the retroviral vectors LiresGFP, RI $\alpha$ ABiresGFP, EGFPIN, or PKIEGFPIN. Beginning on the sixth day in culture, noninfected neuron-Schwann cell cocultures were exposed to H-89 $(10 \mu \mathrm{M})$ or KT5720 $(1,5$, or $10 \mu \mathrm{M})$ for a total of $48 \mathrm{hr}$. On the seventh day in culture, medium on infected cultures, noninfected control cultures, and noninfected cultures exposed to inhibitors were supplemented to contain $50 \mu \mathrm{M} \mathrm{BrdU}$ in the presence or absence of $\mathrm{H}-89$ or K T5720 for $24 \mathrm{hr}$. The percentage of Schwann cells that were $\mathrm{BrdU}^{+}$was then determined by immunocytochemical detection of BrdU-labeled cells. Data are the mean \pm SD of three independent experiments. Significance of differences was determined with a $t$ test $\left(n=3 ; * p<0.02 ;{ }^{* *} p<0.005\right)$.

with PKIEGFPIN or RI $\alpha$ ABiresGFP resulted in an $80 \%$ reduction in the total number of myelin segments per coverslip compared with cultures infected with the control vectors EGFPIN or LiresGFP (Fig. 7B).

\section{DISCUSSION}

Neuron-Schwann cell interactions are critical for proper development and regeneration of the peripheral nervous system. Many reports document that neuronal contact and cAMP elevation have similar effects on Schwann cell mitosis and the expression of myelin-associated molecules, suggesting that neuronal contact may exert its effects by elevating Schwann cell cAMP. Therefore, we wished to test the hypothesis that activation of Schwann cell PKA is necessary for the neuronal stimulation of Schwann cell mitosis and myelin formation. To achieve this, retroviral vectors were used to deliver genes encoding highly specific PKA inhibitory proteins selectively to Schwann cells cocultured with neurons.

The retroviral vectors we describe use a dicistronic design to facilitate inhibition of PKA and identification of infected cells. Two variants of GFP have been used to identify infected cells. The vectors LiresGFP and RI $\alpha$ ABiresGFP use GFP(S65T) 3' of the ires. Translation of coding sequences $3^{\prime}$ of an ires can be comparable with or significantly less than the $5^{\prime}$ cap-mediated expression of an upstream coding sequence. Consequently, a direct correlation between the intensity of the GFP and the level 

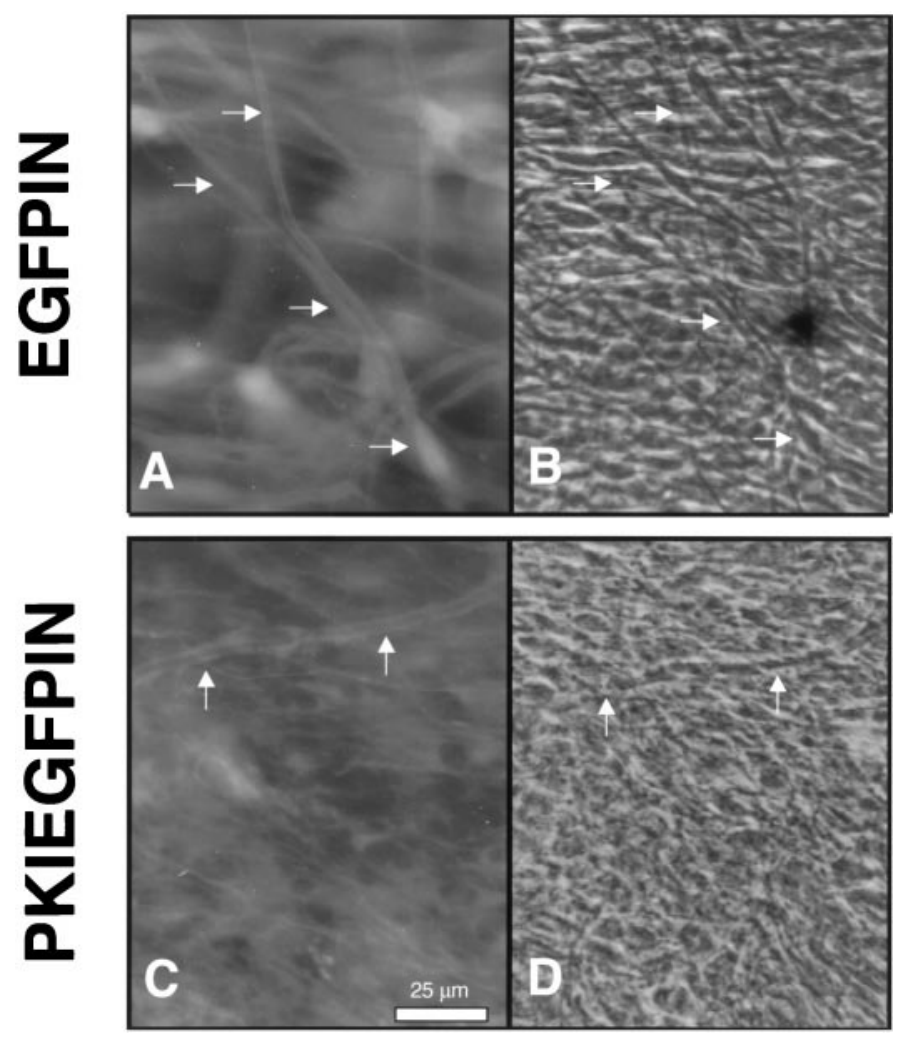

Figure 6. Myelin formed in EGFPIN-infected cultures is visible on examination under phase and epifluorescence. $\mathrm{SC}_{\text {DRG }}$ were infected with EGFPIN or PKIEGFPIN on 3 consecutive days in culture. After $\sim 10 \mathrm{~d}$ of expansion on neurites in defined medium, cultures were grown in $\mathrm{MM}+$ for $10 \mathrm{~d}$. Myelin was a prominent feature of EGFPIN-infected cultures and was clearly visible on examination using either epifluorescence $(A)$ or phase-contrast $(B)$ microscopy. In contrast, myelin formation was markedly reduced in PKIEGFPIN-infected cultures examined with both epifluorescence $(C)$ and phase-contrast $(D)$ microscopy. Arrows indicate the relative position of myelin segments in each pair of photographs. The myelinating Schwann cell in $C$ and $D$ is the only example we observed of a PKIEGFP-expressing Schwann cell that appeared to have initiated myelination. Scale bar, $25 \mu \mathrm{m}$.

of $\mathrm{RI} \alpha \mathrm{AB}$ expression cannot be made. Low-intensity GFP expression therefore does not necessarily indicate low expression levels of RI $\alpha \mathrm{AB}$. In contrast, PKIEGFPIN and EGFPIN use a significantly brighter GFP variant (EGFP). EGFP is fused to PKI, and PKIEGFP expression is independent of an ires. These changes resulted in expression of PKIEGFP that was easily detected visually and the intensity of which should be directly correlated with the level of PKI and thus PKA inhibition. Because both PKIEGFPIN and RI $\alpha$ ABiresGFP had dramatic and equivalent effects in all experiments, we feel that the expression level achieved by both of these vectors was sufficient to functionally inhibit PKA.

Traditionally, in vitro assays are performed to evaluate PKA activity in cell extracts. The limited amount of protein available from infected Schwann cell minicultures did not permit this type of in vitro biochemical analysis. Expansion of infected Schwann cells with forskolin and growth factors was not attempted, because this is a PKA-dependent process and was inhibited by our PKA inhibitory retroviral vectors. Experiments examining cAMP response element-binding protein (CREB) phosphorylation were performed in an attempt to demonstrate more directly the effect of the PKA inhibitory retroviral vectors on Schwann
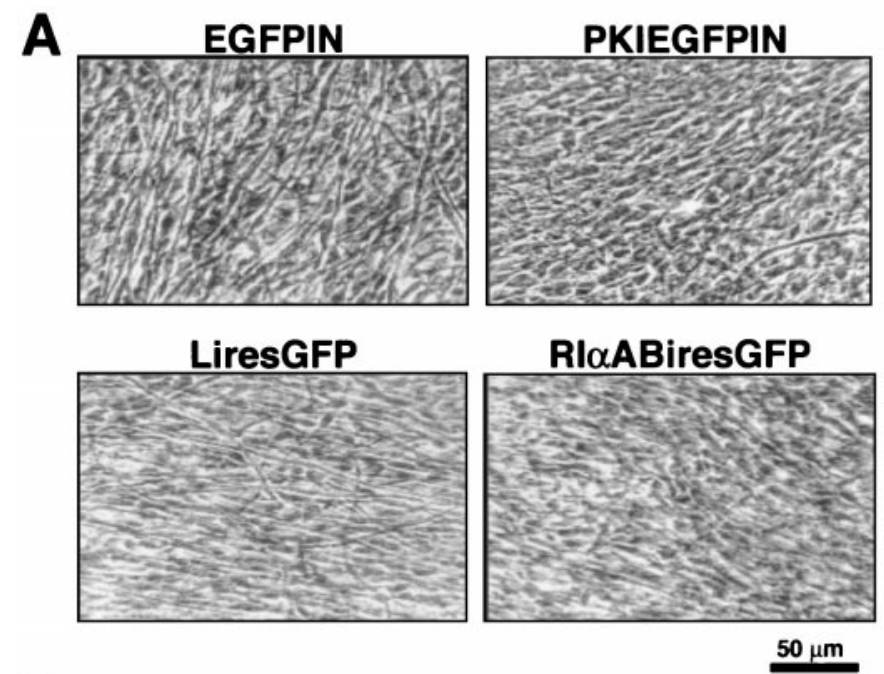

B

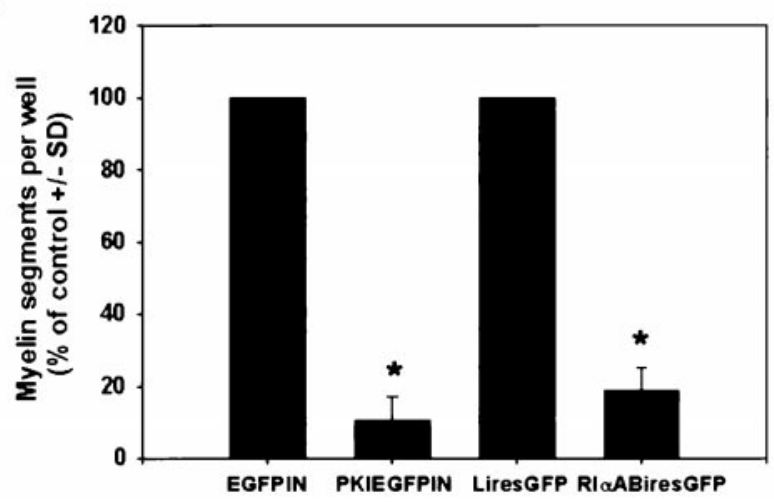

Figure 7. Infection of Schwann cells expanding from DRG explants with PKIEGFPIN or RI $\alpha$ ABiresGFP inhibits myelin formation. Schwann cells expanding from DRG explants were infected with the retroviral vectors EGFPIN, PKIEGFPIN, LiresGFP, or RI $\alpha$ ABiresGFP. $A$, After $10 \mathrm{~d}$ in $\mathrm{MM}+$ to promote myelin formation, cultures were stained with Sudan black. $B$, Schwann cell bodies associated with Sudan black-stained myelin segments were counted over the entire surface area of each coverslip. Within each experiment, the number of myelin segments formed in cultures infected with PKIEGFPIN or RI $\alpha$ ABiresGFP was normalized to that in EGFPIN or LiresGFP control cultures, respectively. The data are the mean $\pm \mathrm{SD}$ of three independent experiments. Significance of differences was determined by a one-sample $t$ test $(n=3$; $* p<0.0025)$.

cell PKA. Unfortunately, CREB phosphorylation was not detected in Schwann cells after treatment with either forskolin or bovine pituitary extract. These experiments were performed using immunocytochemical methods and phosphoCREB antibodies obtained from two different commercial sources. Elevation of Schwann cell cAMP enhances stimulation of mitosis by several growth factors (Davis and Stroobant, 1990; Weinmaster and Lemke, 1990; Stewart et al., 1991) and induces significant morphological changes (Sobue et al., 1986; Muir et al., 1989). Forskolin-stimulated mitosis and morphological change were thus used as indirect functional assays to assess PKA activity in infected Schwann cells. Infection of Schwann cells with PKA inhibitory retroviral vectors completely blocked the ability of forskolin to stimulate Schwann cell mitosis evaluated by measures of cell density, as well as by counting the size of individual Schwann cell clones. In experiments with Schwann cell clones, examination of the cultures shortly after plating at low density 
indicated that the vast majority of the cells were isolated as single cells. However, it is possible that a small percentage of the cell clusters examined originated from more than one infected Schwann cell. The low frequency with which this may have occurred is not likely to have affected the results. Morphological changes caused by treatment of Schwann cells with forskolin were also completely blocked by infection of Schwann cells with PKA inhibitory but not control retroviral vectors. These results strongly indicate that signaling through PKA is substantially inhibited in Schwann cells infected with PKIEGFPIN or RI $\alpha$ ABiresGFP.

The importance of Schwann cell PKA in neuronal stimulation of Schwann cell mitosis was evaluated with chemical and retroviral inhibitors of PKA. H-89 and KT5720 significantly inhibited neuronal stimulation of Schwann cell mitosis, consistent with the data of Kim et al. (1997). However, this approach results in PKA inhibition in both neurons and Schwann cells. In contrast to the results with chemical inhibitors, inhibition of PKA in Schwann cells by infection with PKA inhibitory retroviral vectors had no effect on neuronal stimulation of Schwann cell mitosis. One possibility that cannot be completely ruled out is that the PKA inhibitory proteins were not expressed at a high enough level to inhibit Schwann cell mitosis stimulated by interaction with neurons. We feel that this is unlikely for several reasons. Both PKA inhibitory vectors essentially prevented myelination, demonstrating their ability to block a complex neuron-mediated effect on Schwann cells. In addition, both PKA inhibitory vectors completely blocked the ability of forskolin to stimulate Schwann cell mitosis and morphological changes yet had a complete lack of effect on neuronal stimulation of mitosis. The profound effect of these vectors on myelination and on the ability of forskolin to stimulate Schwann cell mitosis and morphological change strongly suggests that they inhibited PKA activity to a significant extent. Both PKI and RI $\alpha$ AB have subnanomolar $K_{\mathrm{d}}$ values for PKA, demonstrating the high affinity of their association and thus their high potency (Hofmann, 1980; Scott et al., 1986; Herberg and Taylor, 1993). Once bound to the PKA catalytic subunit, $\mathrm{RI} \alpha \mathrm{AB}$ is stabilized and sequesters catalytic subunits. This mechanism is thought to play an important role in the potent effect of $\mathrm{RI} \alpha \mathrm{AB}$, even when expressed at low levels (Corell et al., 1989). One possibility consistent with our observations is that $\mathrm{H}-89$ and KT5720 are exerting their effects on Schwann cell mitosis by inhibition of PKA in neurons. Chemical inhibitors of PKA affect the development of neurites from PC12 cells and cultured hippocampal neurons, raising the possibility that these inhibitors may prevent neurons from delivering the mitogenic signal to Schwann cells (Chijiwa et al., 1990; Cabell and Audesirk, 1993). The possible role of neuronal PKA in modulating Schwann cell phenotype will be an interesting area for further investigations.

An additional consideration is the specificity of the inhibitors. Both H-89 and KT5720 are competitive with ATP for binding to the PKA catalytic subunit and therefore may have non-PKAdependent effects in common (Kase et al., 1987; Chijiwa et al., 1990). At least one report documents inhibition of Schwann cell mitogen-activated protein kinase (MAPK) in intact cells by $\mathrm{KT} 5720$, finding that $\mathrm{KT} 5720$ has an $\mathrm{IC}_{50}$ of $1.0 \mu \mathrm{M}$ for MAPK, $5.8 \mu \mathrm{M}$ for PKC, $3.7 \mu \mathrm{M}$ for cdc2, and $1.4 \mu \mathrm{M}$ for PKA (Olsen et al., 1998). The neuronal stimulation of Schwann cell mitosis is mediated by neuregulin stimulation of ErbB receptors on Schwann cells (Levi et al., 1995; Morrissey et al., 1995). Because MAPK is a downstream effector of activated ErbB receptors, inhibition of MAPK by KT5720 is one possible explanation for the ability of this inhibitor to block neuronal stimulation of Schwann cell mitosis. The inability of PKA inhibitory retroviral vectors to inhibit neuronal stimulation of Schwann cell mitosis is consistent with this possibility. PKI and RI $\alpha \mathrm{AB}$ are highly specific for PKA, and no direct inhibition of the MAPK pathway would be expected.

It has been reported recently that both $\beta$-neuregulin and neuronal contact induce sustained phosphorylation of CREB at serine 133 (Tabernero et al., 1998; Lee et al., 1999). This $\beta$-neuregulin-induced CREB phosphorylation is mediated at least in part via activation of the MAPK pathway. Rahmatullah et al. (1998) reported activation of extracellular signal-regulated kinase (ERK) and ERK2 in Schwann cells after exposure to $\beta$-neuregulin, and Tabernero et al. (1998) reported that $\beta$-neuregulin-induced CREB phosphorylation was reduced by treatment with the MAPK kinase inhibitor PD98059. However, sustained CREB phosphorylation and Schwann cell division were only observed when cells were exposed to both elevation of cAMP and $\beta$-neuregulin (Rahmatullah et al., 1998). These reports suggest that maximal stimulation of Schwann cell mitosis requires both activation of MAPK and cAMP-dependent signals in Schwann cells. Our results suggest that neuronal stimulation of Schwann cell mitosis does not require activation of cAMPdependent protein kinase in Schwann cells. These data raise the possibility that agents that increase cAMP facilitate phosphorylation of CREB and mitogenic signaling in Schwann cells via a PKA-independent mechanism. The recently described family of cAMP-binding guanine nucleotide exchange factors (cAMPGEFs) provide one possible mechanism by which agents that elevate cAMP could facilitate signaling in the MAPK pathway. cAMP-GEFs were shown recently to bind cAMP and directly activate Rap1A in a cAMP-dependent and PKA-independent manner (Kawasaki et al., 1998). Rap1 is known to activate the MAPK pathway via its interaction with B-Raf (Ohtsuka et al., 1996; York et al., 1998). The possibility that cAMP-GEFs play an important role in neuron-Schwann cell interactions will be an interesting area for further investigations.

Many reports have documented that neuronal contact with Schwann cells can induce myelin formation. We addressed the importance of Schwann cell PKA in myelin formation using $\mathrm{SC}_{\mathrm{DRG}}$ infected with PKA inhibitory retroviral vectors. Schwann cells expressing the PKA inhibitory proteins PKIEGFP or $\mathrm{RI} \alpha \mathrm{AB}$ failed to myelinate DRG neurons. In comparison, $\mathrm{GFP}^{+}$ myelin segments were abundant in LiresGFP- and EGFPINinfected control cultures, strongly suggesting that activation of PKA is an important event in the process of myelination by Schwann cells. This result further supports our contention that PKA activity was significantly inhibited in Schwann cells infected with RI $\alpha$ ABiresGFP or PKIEGFPIN. It is clear that Schwann cell cAMP levels are elevated in myelinating nerves by modulation of adenylyl cyclase and phosphodiesterase activities (Poduslo et al., 1995; Walikonis and Poduslo, 1998). P0 gene induction occurs before cAMP elevation in regenerating sciatic nerve endoneurial explants, and cAMP levels reached only $27 \%$ of control values by $35 \mathrm{~d}$ after a crush injury, a time when the remyelination process is virtually complete (Poduslo et al., 1995). The results of these studies demonstrate that elevation of cAMP occurs in actively myelinating but not nonmyelinated nerves and that expression of at least some myelin proteins may be independent of cAMP elevation. However, these results do not preclude the possibility that cAMP and PKA play an important role in the formation or stabilization of myelin sheaths. Additionally, it is 
difficult to account for the possible effects of subcellular localization of cAMP and PKA. Perhaps the relatively low level of cAMP present in regenerating nerves is sufficient to support an important role for cAMP and PKA in the process of myelination. Our results suggest that activation of Schwann cell PKA is an important step in the process of myelin formation or stabilization. We do not know the stage at which PKA inhibitory retroviral vectors block myelination. Possibilities include a failure to become quiescent, form a proper basal lamina, execute morphological changes, or express transcription factors, proteins, or lipids required for myelin formation. These will be areas of interest to examine in future studies using the retroviral approach we have taken here or through the use of transgenic and knock-out techniques in mice.

\section{REFERENCES}

Bunge RP (1994) The role of the Schwann cell in trophic support and regeneration. J Neurol 242:S19-S21.

Cabell L, Audesirk G (1993) Effects of selective inhibition of protein kinase $\mathrm{C}$, cyclic AMP-dependent protein kinase, and $\mathrm{Ca}^{2+}$. calmodulin-dependent protein kinase on neurite development in cultured rat hippocampal neurons. Int J Dev Neurosci 11:357-368.

Chijiwa T, Mishima A, Hagiwara M, Sano M, Hayashi K, Inoue T, Naito K, Toshioka T, Hidaka H (1990) Inhibition of forskolin-induced neurite outgrowth and protein phosphorylation by a newly synthesized selective inhibitor of cyclic AMP-dependent protein kinase, $N$-[2- $(p-$ bromocinnamylamino)ethyl]-5-isoquinolinesulfonamide (H-89), of PC12D pheochromocytoma cells. J Biol Chem 265:5267-5272.

Corell LA, Woodford TA, Corbin JD, Mellon PL, McKnight GS (1989) Functional characterization of cAMP-binding mutations in type I protein kinase. J Biol Chem 264:16672-16678.

Davis JB, Stroobant P (1990) Platelet-derived growth factors and fibroblast growth factors are mitogenic for rat Schwann cells. J Cell Biol 110:1353-1360.

Fernandez-Valle C, Fregien N, Wood PM, Bunge MB (1993) Expression of the protein zero myelin gene in axon related Schwann cells is linked to basal lamina formation. Development 119:867-880.

Gupta SK, Poduslo JF, Dunn R, Roder J, Mezei C (1990) Myelinassociated glycoprotein gene expression in the presence and absence of Schwann cell-axonal contact. Dev Neurosci 12:22-33.

Gupta SK, Pringle J, Poduslo JF, Mezei C (1993) Induction of myelin genes during peripheral nerve remyelination requires a continuous signal from the ingrowing axon. J Neurosci Res 34:14-23.

Hayasaka K, Himoro M, Sato W, Takada G, Uyemura K, Shimizu N, Bird TD, Conneally PM, Chence PF (1993) Charcot-Marie-Tooth neuropathy type $1 \mathrm{~B}$ is associated with mutations of the myelin $\mathrm{Pl}$ gene. Nat Genet 5:31-34.

Herberg FW, Taylor SS (1993) Physiological inhibitors of the catalytic subunit of cAMP-dependent protein kinase: effect of MgATP on protein-protein interactions. Biochemistry 32:14015-14022.

Hofmann F (1980) Apparent constants for the interaction of regulatory and catalytic subunit of cAMP-dependent protein kinase I and II. J Biol Chem 255:1559-1564.

Howe DG, McCarthy KD (1998) A dicistronic retroviral vector and culture model for analysis of neuron-Schwann cell interactions. J Neurosci Methods 83:133-142.

Kase H, Iwahashi K, Nakanishi S, Matsuda Y, Yamada K, Takahashi M, Murakata C, Sato A, Kaneko M (1987) K-252 compounds, novel and potent inhibitors of protein kinase $\mathrm{C}$ and cyclic nucleotide-dependent protein kinases. Biochem Biophys Res Commun 142:436-440.

Kawasaki H, Springett GM, Mochizuki N, Toki S, Nakaya M, Matsuda M, Housman DE, Graybiel AM (1998) A family of cAMP-binding proteins that directly activate Rap1. Science 282:2275-2279.

Kim HA, DeClue JE, Ratner N (1997) cAMP-dependent protein kinase $\mathrm{A}$ is required for Schwann cell growth: interactions between the cAMP and neuregulin tyrosine kinase pathways. J Neurosci Res 49:236-247.

Kulkens T, Bolhuis PA, Wolterman RA, Kemp S, Te Nijenhuis S,
Valentijn LJ, Hensels GW, Jennekens FG, DeVisser M, Hoogendijk JE, Baas F (1993) Deletion of the serine 34 codon from the major peripheral myelin protein Po gene in Charcot-Marie-Tooth disease type 1B. Nat Genet 5:35-39.

Lee MM, Badache A, DeVries GH (1999) Phosphorylation of CREB in axon-induced Schwann cell proliferation. J Neurosci Res 55:702-712.

Levi AD, Bunge RP, Lofgren JA, Meima L, Hefti F, Nikolics K, Sliwkowski MX (1995) The influence of heregulins on human Schwann cell proliferation. J Neurosci 15:1329-1340.

Marrosu MG, Vaccargiu S, Marrosu G, Vannelli A, Cianchetti C, Muntoni F (1998) Charcot-Marie-Tooth disease type 2 associated with mutation of the myelin protein zero gene. Neurology 50:1397-1401.

McCarthy KD, Partlow LM (1976) Neuronal stimulation of $\left[{ }^{3} \mathrm{H}\right]$ thymidine incorporation by primary cultures of highly purified non-neuronal cells. Brain Res 114:415-426.

McKnight GS, Cadd GG, Clegg CH, Otten AD, Correll LA (1988) Expression of wild-type and mutant subunits of the cAMP-dependent protein kinase. Cold Spring Harb Symp Quant Biol 53:111-119.

Mirsky R, Dubois C, Morgan L, Jessen KR (1990) 04 and A007-sulfatide antibodies bind to embryonic Schwann cells prior to the appearance of galactocerebroside; regulation of the antigen by axon-Schwann cell signals and cyclic AMP. Development 109:105-116.

Morgan L, Jessen KR, Mirsky R (1991) The effects of cAMP on differentiation of cultured Schwann cells: progression from an early phenotype $\left(\mathrm{O}^{+}\right)$to a myelin phenotype $\left(\mathrm{Po}^{+}\right.$, GFAP-, N-CAM-, NGFReceptor-) depends on growth inhibition. J Cell Biol 112:457-467.

Morrissey TK, Levi AD, Nuijens A, Sliwkowski MX, Bunge RP (1995) Axon-induced mitogenesis of human Schwann cells involves heregulin and p185erbB2. Proc Natl Acad Sci USA 92:1431-1435.

Muir D, Gennrich C, Varon S, Manthorpe M (1989) Rat sciatic nerve Schwann cell microcultures: responses to mitogens and production of trophic and neurite-promoting factors. Neurochem Res 14:1003-1012.

Oh S, Ri Y, Bennett MV, Trexler EB, Verselis VK, Bargiello TA (1997) Changes in permeability caused by connexin 32 mutations underlie X-linked Charcot-Marie-Tooth disease. Neuron 19:927-938.

Ohtsuka T, Shimizu K, Yamamori B, Kuroda S, Takai Y (1996) Activation of brain B-Raf protein kinase by Rap1B small GTP-binding protein. J Biol Chem 271:1258-1261.

Olsen MK, Reszka AA, Abraham I (1998) KT5720 and U-98017 inhibit MAPK and alter the cytoskeleton and cell morphology. J Cell Physiol 176:525-536.

Poduslo JF, Walikonis RS, Domec MC, Berg CT, Holtz-Heppelmann CJ (1995) The second messenger, cyclic AMP, is not sufficient for myelin gene induction in the peripheral nervous system. J Neurochem 65:149-159.

Politis MJ, Sternberger N, Ederle K, Spencer PS (1982) Studies on the control of myelinogenesis. IV. Neuronal induction of Schwann cell myelin-specific protein synthesis during nerve fiber regeneration. J Neurosci 2:1252-1266.

Rahmatullah M, Schroering A, Rothblum K, Stahl RC, Urban B, Carey DJ (1998) Synergistic regulation of Schwann cell proliferation by heregulin and forskolin. Mol Cell Biol 18:6245-6252.

Salzer JL, Bunge RP (1980) Studies of Schwann cell proliferation. I. An analysis in tissue culture of proliferation during development, Wallerian degeneration, and direct injury. J Cell Biol 84:739-752.

Salzer JL, Bunge RP, Glaser L (1980) Studies of Schwann cell proliferation. III. Evidence for the surface localization of the neurite mitogen. J Cell Biol 84:767-778.

Scott JD, Glaccum MB, Fischer EH, Krebs EG (1986) Primary structure requirements for inhibition by the heat-stable inhibitor of the cAMPdependent protein kinase. Proc Natl Acad Sci USA 83:1613-1616.

Shuman S, Hardy M, Sobue G, Pleasure D (1988) A cAMP analogue induces synthesis of myelin-specific glycoproteins by cultured Schwann cells. J Neurochem 50:190-194.

Sobue G, Pleasure D (1984) Schwann cell galactocerebroside induced by derivatives of adenosine $3^{\prime}, 5^{\prime}$-monophosphate. Science 224:72-74.

Sobue G, Shuman S, Pleasure D (1986) Schwann cell responses to cyclic AMP: proliferation, change in shape, and appearance of surface galactocerebroside. Brain Res 362:23-32.

Stewart HJ, Eccleston PA, Jessen KR, Mirsky R (1991) Interaction between cAMP elevation, identified growth factors, and serum components in regulating Schwann cell growth. J Neurosci Res 30:346-352. 
Tabernero A, Stewart HJS, Jessen KR, Mirsky R (1998) The neuronglia signal beta neuregulin induces sustained CREB phosphorylation on Ser-133 in cultured rat Schwann cells. Mol Cell Neurosci 10:309-322.

Walikonis RS, Poduslo JF (1998) Activity of cyclic AMP phosphodiesterases and adenylyl cyclase in peripheral nerve after crush and permanent transection injuries. J Biol Chem 273:9070-9077.

Wang X, Murphy TJ (1998) Inhibition of cyclic AMP-dependent kinase by expression of a protein kinase inhibitor/enhanced green fluorescent fusion protein attenuates angiotensin II-induced type 1 AT1 receptor mRNA down-regulation in vascular smooth muscle cells. Mol Pharmacol 54:514-524.
Weinmaster G, Lemke G (1990) Cell-specific cyclic AMP-mediated induction of the PDGF receptor. EMBO J 9:915-920.

Woodford TA, Correll LA, McKnight GS, Corbin JD (1989) Expression and characterization of mutant forms of the type I regulatory subunit of cAMP-dependent protein kinase. The effect of defective cAMP binding on holoenzyme activation. J Biol Chem 264:13321-13328.

York RD, Yao H, Dillon T, Ellig CL, Eckert SP, McCleskey EW, Stork PJ (1998) Rap1 mediates sustained MAP kinase activation induced by nerve growth factor. Nature 392:622-626.

Zolotukhin S, Potter M, Hauswirth WW, Guy J, Muzyczka N (1996) A "humanized" green fluorescent protein cDNA adapted for high- level expression in mammalian cells. J Virol 70:4646-4654. 